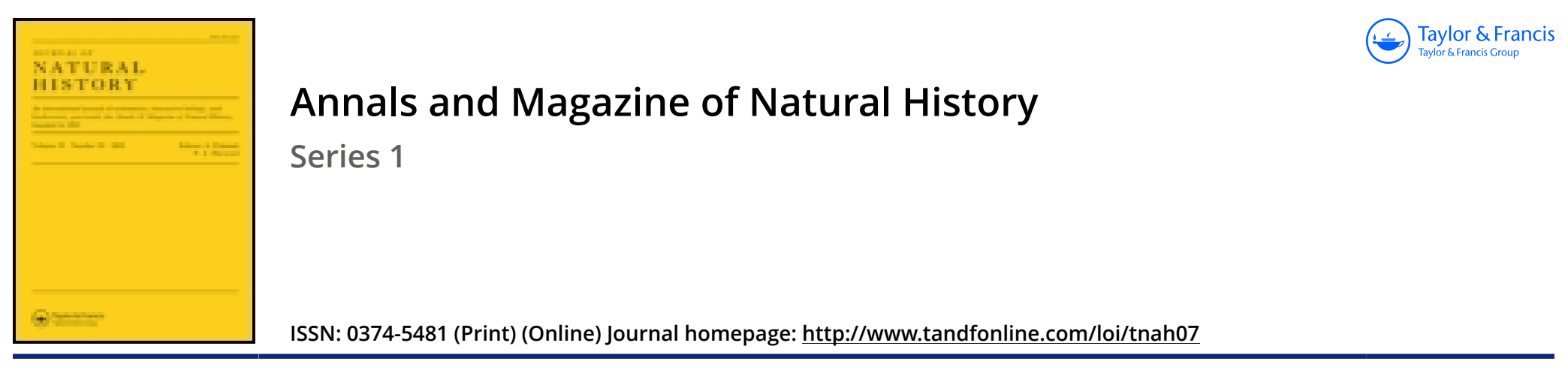

\title{
Viola lactea
}

\section{Sir W.J. Hooker}

To cite this article: Sir W.J. Hooker (1839) Viola lactea, Annals and Magazine of Natural History, 2:11, 383-383, DOI: 10.1080/00222933909512414

To link to this article: http://dx.doi.org/10.1080/00222933909512414

曲 Published online: 15 Mar 2010.

Submit your article to this journal $\widetilde{ }$

Q View related articles $\longleftarrow$ 


\section{VIOLA LAC'TEA.}

A very excellent botanist and one of our most "zealous" pupils, John Nicholson, Esq., of Lincoln, has found a very remarkable state of Viola lactea, Linn., 'E. Bot.' t. 445, in the neighbourhood of that city (at Boultham Lane, on both sides of the road), in habit so unlike the figure just quoted that it might at first sight be taken for a distinct species. Except at the base the stems are quite erect, and many of the specimens from a foot to eighteen inches tall, with the leaves and peduncles very remote from each other, and many of the flowers apetalous. Reichenbach's V. lactea, 'Iconogr. Bot.' t. 99, however, admirably represents this variety, only that the latter is much smaller, not above a span high. Its flowers are very pale blue, almost milk-coloured, otherwise it is hardly to be distinguished from some states of Viola montana, L.-Sin W. J. НоокеR.

\section{METEOROLOGICAL OBSERVATIONS FOR NOVEMBER 1838.}

Chiswich--Nov. 1. Overcast : rain : clear at night. 2,3. Fine. 4. Rain. 5. Fine. 6. Very fine. 7. Rain: fine: windy at night. 8. Clear and fine: rain. 9. Heavy rain. 10. Clear and fine. 11. Dense fog. 12, Clear and cold. 13. Frosty : fine. 14. Frosty and foggy. 15, 16. Foggy. 17. Foggy : fine. 18, 19. Rain. 20. Cold haze. 21-23. Foggy. 24. Bleak and cold. 25, 26. Fiosty. 27. Overcast. 28. Heavy rain: hurricane at night. 29. Boisterous with heavy rain: much thunder and lightning at night. 30. Rain. fine.

Boston.-Nov, 1. Fine : rain early A.M. 2, 3. Fine: rain P.M. 4. Clondy: rain P.м. 5. Cloudy. 6. Fine. 7. Cloudy : rain early a.m. 8. Fine. 9, 10. Cloudy. 11. Foggy, 12, 15. Fine. 14. Foggy. 15. Cloudy. 16, 17. Foggy. 18. Cloudy : rain A. M. and P.M. 19. Stormy. 20, 21. Cloudy. 22. Cloudy: rain early A. M. 23, 24. Cloudy. 25, 26. Fine. 27. Stormy. 28. Cloudy : stormy with rain P.M. 29. Stormy : rain early A.M. 30. Stormy.

Applegarth Manse, Dumfries-shire.-Nov. 1. Heavy showers: hail. 2. Fair but cloudy. 3. Frequent showers. 4. Fair and cloudy. 5. Moist: slight showers. 6. Fair: one slight shower. 7. Rain all day : high flood. 8. Occasional showers. 9. Fine day. 10. Fine day : rain P.M. 11. Fine day after snow. 12, Hard frost : clear and serene. 13. Temperate. 14. Cloudy and raw. 1E. Thick fog. 16. Cleared up: dry. 17. Rain in the night : cold. 18. Cold drying day : snow on hills. 19. Cold and threatening a fall. 20. Still cold, yet dry. 21. Still threatening a fall. 22-26. Cold and dry. 27. Cold : snow three inches deep. 28. Wet in the night: ditto r.kr. 29. Very wet day and storny. 30. Showery and stormy: flood. 